\title{
The Research of OFDI Location Choice of China to the "One Belt and One Road" Countries
}

\author{
Peizhi Wang \\ College of International Economics and Trade \\ Shandong University of Finance and Economics \\ Jinan, Shandong, China \\ wpzmail@126.com
}

\author{
Xinyi Pan* \\ College of International Economics and Trade \\ Shandong University of Finance and Economics \\ Jinan, Shandong, China \\ 18562141268@163.com
}

\begin{abstract}
To accelerate the OFDI of China to the "OBOR" countries and explore the influence factors of OFDI location choice, this article selects the data of China to 35 countries along “One Belt and One Road" during 2005-2014, using extended gravity model to analyze the influence factors of OFDI location choice. Inspection analysis shows that some factors are significant positive impact on the OFDI location choice of China to the "OBOR" countries, such as larger economies of scale, abundant natural resources endowment, high per capital national income and similar to China's institutional environment; geographic distance has negative impact on OFDI and technological level has no significant influence on OFDI. As a result, China's OFDI should pay more attention to the host countries' GDP, natural resources and geographic distance, strengthen the analysis of institutional environment.
\end{abstract}

Keywords-One Belt and One Road; OFDI; Location choice; Institutional environment Introduction

\section{INTRODUCTION}

In September 2013, President Xi made major strategic vision for One Belt And One Road during his visit to central Asia and ASEAN firstly. With the help of the "silk road" symbol and the existing bilateral and multilateral mechanism between China and relevant countries, "OBOR" strategy actively promotes the along countries' economic cooperation and bilateral trade cooperation, responds to the desire of the along countries to strengthen mutually beneficial cooperation and shows China's determination to further open. Since the "One Belt And One Road" proposed three years, Cooperation between China and the One Belt And One Road countries has increased significantly, realizing the common development of participating countries. The "OBOR" strategy's impact quickly spreads across the globe.

From the perspective of capital formation, foreign direct investment (FDI) is an important driver of economic growth in a country. Since 1980, with the implementation of the reform and opening up policy, a surge in foreign direct investment in mainland China, the scale expands unceasingly, for China's economic development and upgrading of industrial structure playing an irreplaceable role, since 2012 China has become one of the world's largest FDI recipient. Meanwhile, capital flows is a two-way street, in plenty of attracting FDI in China, at the same time, China's outward foreign direct investment (OFDI) is also gradually expand, in 1999 the Chinese government policies to promote the development of OFDI, the growth of China's OFDI began, according to world investment report of 2016's data shows that in 2015 China has become the world's second largest foreign direct investor.

With the increase of foreign direct investment in China, the distribution and influencing factors of its location are highly concerned by academic circles. Sue Claire Berning and Dirk Holtbrügge(2012)[1], Marjorie Lyles, Dan Li and Haifeng Yan(2014)[2], William Sheng Liu and Yanmin Shao, Yan Shang(2016)[3] were using different data to explore the influence of OFDI location choice, which found that some factors can affect China's OFDI, such as the economic scale and the inflation rate of the host country, the bilateral trade volume, the bilateral exchange rate, the per capita income difference of the two countries, the institutional environment factor and the cultural distance.

After the "OBOR" strategy putting forward, Jialing Zou (2015)[4]、Zhonghua Cai(2016)[5] and Chunan Sun(2017)[6] studied the OFDI of China to the "OBOR" countries and came up with many valued proposal. In the foreign direct investment location choice, the countries along the "One Belt And One Road" have always been an important area for attracting China's OFDI. The economic structure of China and the One Belt And One Road countries are highly complementary to each other, which is embodied in: China is relatively short of natural resources, with huge demand and huge overcapacity in some industries. On the contrary, the "OBOR" countries have rich natural resources, but the infrastructure is inadequate, the industrial base is weak and the two sides can form a good complementary relationship.

The investment flow combined $\$ 13.65594$ billion, which was 21.8 times to 2005 . With the rapid development of Chinese enterprises to invest in the "OBOR" countries, the relevant issues are widely concerned, especially which countries along "OBOR" should choose to invest. To determine the target country of China's foreign direct investment, we should analyze the influence factors of OFDI location choice of China to the "One Belt and One Road" countries and the foreign investment motives of Chinese companies. For this reason, this article selects the data of China to 35 countries along "One Belt and One Road" during 2005-2014 to analyze the influence factors of OFDI location choice. 


\section{MODEL HYPOTHESIS AND VARIABLE SELECTION}

\section{A. Model hypothesis}

When using the investment gravity model to study the influence factors of the location distribution, the study variables for the test need to be studied, and the original investment gravity model is usually transformed. This article sets the investment gravity model in the following form:

$$
\ln o f d i_{i j t}=\beta_{0}+\beta_{1} \ln g d p_{i t}+\beta_{2} \ln g d p_{j t}+\beta_{3} \ln d i s+\sum_{n} \beta_{n} C_{n j t}+\mu_{t}
$$

In the model, ofdiijt shows the OFDI of country i to country $\mathrm{j}$ in t year; gdpit shows the investment country's GDP in t year; gdpjt shows the host country's GDP in t year; dis shows the distance between investment country and host country. GDP and DIS are the base variables of the investment gravity model. Cnjt shows another variables which may affect the OFDI of China to the "OBOR" countries.

\section{B. Variable selection}

To avoid the problem of sample selection, this paper considers the factors such as scale of investment and continuity, selecting the data of China to 35 countries along "One Belt and One Road" during 2005-2014 to analyze the influence factors of OFDI location choice.

Explained variable: We select the OFDI flows of China to the "OBOR" countries to be explained variable, data from China's foreign direct investment communique during 20052014.

This article selects the following variables as the core interpretation variables:

Market size of host country: The market search is one of the important motivations of the Chinese company OFDI, the total GDP of the host country is an important indicator of the market size of the host country. This paper measures the market size of the host country's GDP, which is derived from the United Nations statistical office database.

Natural resources endowment of host country: As the shortage of domestic resources, seeking for natural resources become important driving factors of China's OFDI, this article selects the host country fuel, mineral and metal exports accounted for the proportion of export goods (nr) as the explanatory variable to measure the natural resources of the country's abundance, data from the United Nations commodity trade database.

Labor costs of host country: Host countries wages are the important factors influencing the efficiency type seeking OFDI, because of the "OBOR" countries' wage level data are difficult to obtain, this article uses the host country per capital national income (pgni) indirect measures the labor costs, data from world bank database.

Institutional environment of host country: Institutional environment index comes from the Worldwide Governance Indicators published by the World Bank, which including six child pointers, grading section is $(-2.5,2.5)$. This paper selects Control of Corruption, Regulatory Quality and Voice and Accountability to measure the institutional environment of the host country. In addition, we use the absolute value difference of China's institutional environment score and host country's institutional environment score to study how the similar institutional environment affects the OFDI.

Furthermore, we use exchange rate and GDP growth rate to be the control variable.

\section{EMPIRICAL ANALYSIS}

\section{A. Influence factors of investment motives test}

TableI shows the influence factors of investment motives test results. $\operatorname{lngdp}_{\mathrm{i}}$ (China's GDP) is significant influence on the OFDI at the $1 \%$ level, the minimum coefficient is 1.695 , which shows that the expansion of China's economy has a significant positive effect on the OFDI of China to the "OBOR" countries. This shows that as China's economic strength increases, the total amount of capital increases, and China's outward direct investment tends to increase. $\operatorname{lngdp_{j}}$ (host country's GDP) is significant influence on the OFDI at the $1 \%$ level, which suggests that the greater the economic scale of the host country, the stronger the appeal of the Chinese OFDI. The coefficient of lndis is minus, so the geographic distance will have negative effects on the OFDI of China to the "OBOR" countries.

As for other core interpretation variables test, the coefficient of lnnr (host country natural resources endowment) is significant and plus, which shows that the OFDI of China to the "OBOR" countries is tied to the natural resources of the host country, the rich natural resources are attractive to Chinese enterprises and it has obvious resources for seeking incentives. Lnhtec (high-tech exports account for the share of manufactured exports) is not significant, which suggests that OFDI of China to the "OBOR" countries has no obvious technology for motivation. The reasons may be the countries along the "OBOR" for emerging economies and developing countries, compared with China, their technological competitiveness are weak, technology spillover of Chinese enterprises in the local can get less. lnpgni (The national income per capital of the host country) is significant influence on the OFDI. Because China's high value-added investment demand is greater than the investment in labor-intensive industries and countries with more developed services have higher incomes per capital, the resulting impact is significant greater than that of the low labor costs, so the coefficient is plus. lnexch( the exchange rate) is significant and plus, which shows that the appreciation of the RMB makes the RMB more purchasing power than other currencies and it is beneficial to OFDI. Growth (GDP growth rate of host country) has no significantly influence on OFDI. 
TABLE I

INFLUENCE FACTORS OF INVESTMENT MOTIVES TEST

\begin{tabular}{|c|c|c|c|}
\hline & (1) & (2) & (3) \\
\hline VARIABLES & lnofdi & lnofdi & lnofdi \\
\hline \multirow[t]{2}{*}{ lngdpi } & $1.743^{* * * *}$ & $1.695 * * *$ & $1.771 * * *$ \\
\hline & $(0.182)$ & $(0.186)$ & $(0.170)$ \\
\hline \multirow[t]{2}{*}{$\operatorname{lngdpj}$} & $0.459 * * *$ & $0.582 * * *$ & \\
\hline & $(0.173)$ & $(0.186)$ & \\
\hline \multirow[t]{2}{*}{ lndis } & $-1.887 * *$ & $-1.763 * *$ & $-2.249 * *$ \\
\hline & $(0.836)$ & $(0.880)$ & (0.880) \\
\hline \multirow[t]{2}{*}{ lnexch } & $0.208^{* *}$ & $0.175^{*}$ & $0.289 * * *$ \\
\hline & $(0.0958)$ & (0.0999) & $(0.0953)$ \\
\hline \multirow[t]{2}{*}{ growth } & $0.0336^{*}$ & 0.0299 & 0.0243 \\
\hline & $(0.0202)$ & $(0.0204)$ & $(0.0192)$ \\
\hline \multirow[t]{2}{*}{$\operatorname{lnnr}$} & $0.318^{* *}$ & & \\
\hline & $(0.133)$ & & \\
\hline \multirow[t]{2}{*}{ lnhtec } & & -0.110 & \\
\hline & & $(0.0991)$ & \\
\hline \multirow[t]{2}{*}{ lnpgni } & & & $0.879 * * *$ \\
\hline & & & $(0.274)$ \\
\hline \multirow[t]{2}{*}{ Constant } & $-40.07 * * *$ & $-41.85 * * *$ & $-33.51 * * *$ \\
\hline & $(8.258)$ & (8.517) & $(8.421)$ \\
\hline Wald & 213.25 & 205.83 & 253.30 \\
\hline $\mathrm{R} 2$ & 0.4499 & 0.3915 & 0.4317 \\
\hline
\end{tabular}

Exports) is not significant, which suggests that OFDI of China to the "OBOR" countries has no obvious technology for motivation. The reasons may be the countries along the "OBOR" for emerging economies and developing countries, compared with China, their technological competitiveness are weak, technology spillover of Chinese enterprises in the local can get less. lnpgni (The national income per capital of the host country) is significant influence on the OFDI. Because China's high value-added investment demand is greater than the investment in labor-intensive industries and countries with more developed services have higher incomes per capital, the resulting impact is significant greater than that of the low labor costs, so the coefficient is plus. lnexch( the exchange rate) is significant and plus, which shows that the appreciation of the RMB makes the RMB more purchasing power than other currencies and it is beneficial to OFDI. Growth (GDP growth rate of host country) has no significantly influence on OFDI.

\section{B. Institutional environmental factors test}

TABLE II INSTITUTIONAL ENVIRONMENTAL FACTORS TEST

\begin{tabular}{|c|c|c|c|}
\hline & (1) & (2) & (3) \\
\hline VARIABLES & lnofdi & lnofdi & lnofdi \\
\hline \multirow[t]{2}{*}{ Lngdpi } & $1.808^{* * * *}$ & $1.794 * * * *$ & 1.772 *** \\
\hline & $(0.171)$ & $(0.170)$ & $(0.171)$ \\
\hline \multirow{2}{*}{ lngdpj } & $0.440 * * *$ & $0.447 * * *$ & $0.492 * * *$ \\
\hline & $(0.159)$ & $(0.157)$ & $(0.159)$ \\
\hline \multirow[t]{2}{*}{ lndis } & $-1.677 * *$ & $-1.710 * *$ & $-1.729 * *$ \\
\hline & $(0.846)$ & $(0.832)$ & $(0.836)$ \\
\hline \multirow[t]{2}{*}{ lnexch } & $0.168^{*}$ & $0.215^{* *}$ & 0.140 \\
\hline & $(0.0927)$ & $(0.0923)$ & $(0.0938)$ \\
\hline \multirow[t]{2}{*}{ growth } & 0.0274 & $0.0327 *$ & 0.0288 \\
\hline & (0.0192) & $(0.0193)$ & $(0.0192)$ \\
\hline \multirow[t]{2}{*}{$\mathrm{CC}$} & 0.514 & & \\
\hline & $(0.315)$ & & \\
\hline \multirow[t]{2}{*}{ RQ } & & 0.127 & \\
\hline & & $(0.348)$ & \\
\hline \multirow[t]{2}{*}{ VA } & & & $-0.547 *$ \\
\hline & & & $(0.304)$ \\
\hline \multirow[t]{2}{*}{ lnadcc } & $-0.184 *$ & & \\
\hline & $(0.111)$ & & \\
\hline \multirow[t]{2}{*}{ lnadrq } & & $-0.317 * *$ & \\
\hline & & $(0.143)$ & \\
\hline \multirow[t]{2}{*}{ lnadva } & & & $-0.265^{*}$ \\
\hline & & & $(0.136)$ \\
\hline Constant & $\begin{array}{c}-42.5 * * * \\
(7.971)\end{array}$ & $\begin{array}{c}-41.9 * * * \\
(7.863)\end{array}$ & $\begin{array}{c}-42.2^{* * * *} \\
(7.900)\end{array}$ \\
\hline Wald & 253.99 & 257.75 & 255.73 \\
\hline $\mathrm{R} 2$ & 0.3799 & 0.4395 & 0.4372 \\
\hline
\end{tabular}

Formatted In the test of tableII, we use the institutional environment and the absolute difference of the institutional environment to run the regression with fundamental variables respectively. Fundamental variables coefficient and significance of gravity model don't have changed too much. CC (Control of Corruption) and RQ (Regulatory Quality) have positive influence on the OFDI of China to the "OBOR" countries but the effect is not significant. This may be explained by the following reasons: With the establishment and development of China's modern enterprise management system, enterprises pay more attention to maximize shareholder's equity and profits, consciousness constantly improve the system of Chinese enterprises to avoid risk, more and more Chinese enterprises tend to invest and corruption in countries with high quality control and supervision, both to reduce corporate bribery cost, and can ensure shareholder interests, also can avoid the risk of information asymmetry cause. VA (Voice and Accountability) is significant influence on the OFDI at the $10 \%$ level and the coefficient is minus. This may 
be that the high commercial environment of democracy and democracy, lower business environment in the access to information, trade union rights, welfare level exist significant differences in many aspects. Chinese investors have been doing business in authoritarian political systems for years, with relatively low levels of commercial environmental democracy.

The examination of the difference between the host country's institutional environment and the Chinese institutional environment shows that adcc(absolute difference of Control of Corruption), adrq(absolute difference of Regulatory Quality )and adva(absolute difference of Voice and Accountability) are significant influence on the OFDI at the $10 \%$ level and the coefficients are minus, which suggests that the more closer institutional environment between China and the host country, the more OFDI will have. Generally speaking, the bigger the institutional distance, the more the Chinese companies will adjust to the cost of the host country, and the corresponding profits will be reduced. As a result, the size and number of Chinese companies' OFDI will be reduced. Because Chinese companies have adapted themselves to the domestic institutional environment, they can also respond well to a series of problems that may arise in the current institutional environment. When they go to other countries to invest, if the countries with China's institutional quality differences, they do not know how this new system environment works, So they have to spend a lot of cost to adapt to the new institutional environment, this adaptation costs can make the enterprise the profits of the foreign direct investment, and then reduce the size of the OFDI corresponding.

\section{CONCLUSIONS}

First, China's OFDI to the countries along the "OBOR" shows a remarkable positive correlation with the economic scale of China and initiative countries, and a significant negative correlation with the distance between China and those countries. This is consistent with the conclusions of the traditional gravity model. Exchange rate has a significant role in promoting OFDI, however, the growth rate of GDP in host country does not have marked influence. Second, as we can see from the test of investment motives, China's OFDI to the countries along the "OBOR" has a significant market seeking motivation and natural resource seeking motivation, while the efficiency seeking motivation and technology seeking motivation are not significant. The reason may be that China's high demand for direct investment in services offsets the efficiency seeking motivation and the technical competitiveness of countries along the "OBOR" is weaker than that of China. Third, we find out in the examination of institutional environment that China is positively related to the quality of corruption control and regulation of the countries along the "OBOR" and host countries, but it is not significant, and the right of speech and the accountability system will have a significant negative impact on OFDI. At the same time, through the study of the differences between host country and china, we can see that China's OFDI to the countries along the "OBOR" has significant tendency of similar system.
Taking the above empirical results into account, China should focus on the following aspects in direct investment in the countries along "One Belt and One Road".

First of all, when directly invest in the countries along "One Belt and One Road" , China should be concerned about economy, labor costs and natural resources abundance of the other countries, our enterprises should invest to the countries that have large economy, developed trade in services or rich natural resources based on their own investment needs to improve investment efficiency. In addition, China should give priority to the direct investment in neighboring countries that geographical distance is close, which can not only reduce the dominant transport costs and management costs, and can also reduce the transaction costs and other invisible cost based on economic and cultural impact and integration that formed in many years.

Second, China should strengthen its investment in Singapore and European developed countries. As Singapore and European developed countries have more technical competitiveness than China, strengthening direct investment in these countries will help Chinese enterprises to obtain technical spillovers from local and peripheral developed countries, helping to improve the technological level of our country and promote the upgrading of industrial structure.

Finally, China should strengthen system environment analysis of countries along "One Belt and One Road". As China has a tendency to invest more in countries with similar system, the similarity of the system can also effectively reduce the adaptation costs of Chinese enterprises in overseas markets and improve the efficiency of investment. While the analysis of system environment requires a lot of manpower, material and financial resources. It is difficult for a single enterprise to undertake a comprehensive analysis of the host country system. Therefore, the state should strengthen the analysis of the state system environment along "One Belt and One Road" to guide and help the Chinese enterprises to invest.

\section{REFERENCES}

[1] Sue Claire Berning,Dirk Holtbrügge. Chinese outward foreign direct investment - a challenge for traditional internationalization theories?[J]. Journal für Betriebswirtschaft,2012,623.

[2] Marjorie Lyles,Dan Li,Haifeng Yan. Chinese Outward Foreign Direct Investment Performance: The Role of Learning [J]. Management and Organization Review, 2014, 103.

[3] William Sheng Liu,Frank Wogbe Agbola. Regional analysis of the impact of inward foreign direct investment on economic growth in the Chinese electronic industry[J]. Applied Economics, 2014, 4622.

[4] J., Zou. China and the "One Belt And One Road" countries trade patterns and their economic contributions[J], Progress in Geography,05(2015)598-605. (In Chinese)

[5] Z., Cai. A research of China and the "One Belt And One Road" national patent and export structure relationship: based on the analysis of the sector similarity index[J], International trade problem ,07(2016) 61-71. (In Chinese)

[6] C., Sun, N., Zhang and Y., Liu, The "OBOR" initiative and China's trade growth with countries along the route[J], International trade problem, 02(2017)83-96. (In Chinese) 